\title{
LAND MANAGERS' HETEROGENEITY IN MEDITERRANEAN LANDSCAPES - CONSISTENCIES AND CONTRADICTIONS BETWEEN ATTITUDES AND BEHAVIORS
}

\author{
FILIPE BARROSO $^{1}$, TERESA PINTO-CORREIA ${ }^{1}$ \\ ${ }^{1} I C A A M / E ́ v o r a ~ U n i v e r s i t y$, Universidade de Évora, Polo da Mitra, Edificio Principal, Gab. \\ 204, 7000 Évora, Portugal, email: filipelbarroso@gmail.com
}

Received: $26^{\text {th }}$ April 2014, Accepted: $30^{\text {th }}$ July 2014

\begin{abstract}
European rural landscapes face today several changes, which might indicate that an ongoing transition process is taking place. While these transition processes have been mainly addressed for Western Europe and landscapes dominated by intensive agriculture, they remain to be understood in Southern Europe, where large areas are occupied by extensive farming systems, maintaining a distinctive landscape character. However in Mediterranean areas, new ways of managing the land arise, no longer by the conventional farmers alone but also by a multiplicity of other land managers. Nevertheless, the dominant discourse in the farm sector, both in politics and in individuals, is still focused on production. Therefore to better assess the potential of land managers to adapt to changes and to meet the expectations that society articulates towards the farming sector, a description of the land managers' diversity deserves a renewed attention. A number of questions remain unanswered or only partially answered. Which land managers are contributing more to the changes happening? Which are the drivers that encourage or prevent innovation and changes in the holdings? Do all farmers behave in the same way? Does the attitudes-thoughts get translated into actual behavior-actions? In order to answer these questions a land managers' typology anchored on the multifunctional transition framework is proposed. It aims to understand which land manager type contributes more to the multifunctional transition bounded by non-productivist and productivist strategies in place. This typology exploits the combination between the behaviors-action in the holding and the expressed attitudes-thoughts. To achieve this typology, 373 questionnaires were completed by land managers in South Portugal. Results reveal in some cases inconsistencies between land managers attitudes and their action, in an opposite sense to what has been earlier identified in Northwestern Europe, and reflecting the heterogeneity of Mediterranean agriculture and land ownership. Thus, an understanding of the land managers types will lead us to a better understanding of what are land managers looking for in the landscape they use. This knowledge can support better oriented policies and management decision, certainly more easily accepted by land managers since their views, behaviors, attitudes and opinions are taken in consideration.
\end{abstract}

Keywords: Productivism, Non-productivism, Land Managers, Attitudes-thoughts, Behaviors-actions, typology 
Barroso F., Pinto-Correia T.: Land managers' heterogeneity in Mediterranean landscapes - consistencies and contradictions between attitudes and behaviors.

\section{INTRODUCTION}

Rural landscapes patterns and changes strongly depend on the human intervention along time on the agriculture systems (Naveh \& Lieberman, 1984; Pinto-Correia \& Vos, 2004; Primdahl \& Swaffield, 2010). The changing paradigm of agriculture management is at the core of transition pathways in many rural areas. Productivism, post-productivism, non-productivism, multifunctionality (Wilson, 2007; Robinson, 2008) and recently even "bio-economic productivism" (Marsden, 2011) have been targeted towards a possible conceptualization of these transitions. These transitional regimes have been analysed mostly in North-Western European countries, which have failed to discuss whether the concept has wider applicability for other European contexts, namely the Mediterranean countries (Wilson, 2001; Wilson \& Rigg, 2003; Ortiz-Miranda et al., 2013). Productivism is broadly conceptualised on the basis of an industrially driven agriculture, maximising production and farm modernisation (Wilson, 2007). It is generally seen mainly as a Northern European and American phenomenon (Wilson, 2001). Some authors have shown how post-productivist policies may have been 'imposed' onto Mediterranean countries through the CAP framework, while practices and thinking often continue to be productivist since land managers are still mostly concerned about 'catching' their Northern European counterparts (Wilson, 2001; Pinto-Correia \& Godinho, 2013; Pinto-Correia et al., 2013). Therefore, and because the prefix 'post' may merely denote something which comes after another, in this paper the term 'non-productivism' is used, as it seems more appropriate for the Mediterranean context (Holmes, 2006). Non-productivism is related to the growth of farm pluriactivity, re-orientation towards amenities and multifunctional outcome, the loss of the central position of agriculture in the rural, environmental regulation and a more diverse livelihood strategy (Jack, 2007; Maye et. al., 2009; Vesala \& Vesala, 2010)

In the maelstrom of the different trends, Mediterranean rural landscapes have been under dramatic changes over the last three decades, due on the one hand to an abandonment of traditional agricultural activities, coupled with economic and demographic recession in some areas (Ribeiro et. al., 2013; Pinto-Correia \& Vos, 2004; Pinto-Correia et. al., 2013); on the other hand to an intensification and specialization of forestry and agricultural activities (Stoate et al., 2001; MacDonald et al., 2000; Pinto-Correia et. al., 2013). Much of these changes have been driven by shifts in agricultural and socio-economic policy (Van Berkel et al., 2011). Of equal importance is the increasing tourism, recreational use and the urban-rural migration to these rural areas for lifestyle and naturalistic reasons (Wilson, 2001; Blekesaune et al., 2010; Ortiz-Miranda et al., 2013; Pinto-Correia et. al., 2013), driven by new interests, new actors and new alternative uses (Bjørkhaug \& Richards, 2008; Renting et al., 2009). Therefore the Mediterranean regions are also subject to multiple transition processes, but in a different phase, at a different scale and in different conditions. The literature shows how some actors are embracing a productivist action and thought, where the countryside is seen as a place for production of food and fibre, and management aims to intensify production and maximize profit even though this means an homogenization of the landscape and a decline in the environmental conditions of the holding (Wilson, 2009; Walford, 2003; Elands \& Praestholm, 2008). At the same time, there is also evidence that some other actors are embracing non-productivist action and thought, which is seen as a mirror image of productivism, with a critical thinking about industrialization, the European subsidies and the corporate involvement, a wish to be more independent from the state, to adopt environmentally-friendly farming practices; accept new forms of policy regulation; change the dominant perceptions of the farmer's role, and acknowledge the multiple actor spaces in the countryside (Ward, 1993; Wilson, 2001; Mather et al., 2006; Halfacree, 2007; 
Pinto-Correia et al., 2014). These multiple actors can be of several types. It has been described before how tensions emerge between the two opposite models and all their variations, in context where productivism is dominant (Wilson, 2008 and 2009). This happens not only in between different farms and different actors in a local landscape (Pinto-Correia \& Kristensen, 2013), but also within one single farm and a single land manager: even though they support non-productivist ideas, land managers are often struggling to transmit them in their practices, and may opt to adapt their management so that spatially there is a divide between productive areas and marginal non-used areas, and thus continue a dominant productivist practice (Marsden \& Sonnino, 2008; Sutherland, 2010). In extensive farm system of Southern Europe, some authors have shown how even in systems kept apparently as non-productivist, production keeps on being the main driver of the land manager options, and the productivist ideal is strongly embedded in the farmers self-concept (Bruckmeier \& Tovey, 2009; Pinto-Correia et al., 2013; Pinto-Correia \& Godinho, 2013; Rodrigo \& Veiga, 2009).

To understand the on-going processes, there is thus a need to acknowledge the heterogeneity of human's behavior (actions) and attitudes (thoughts) (Baudry \& Thenail, 2004; Pinto-Correia et al., 2006), and farmers cannot be continually considered as a homogenous entity (Wilson, 1996; Paquette \& Domon, 2003; Morris \& Evans, 2004; Korf \& Oughton, 2006; Guillem et al., 2012). Additionally the notion of farmer also need to go further than keeping just the idea of farmer as a producer (Primdahl \& Kristensen, 2011; Van der Ploeg, 2009). Several designations and names have been used nowadays to define the new conception of farmer, from landholders (those who hold the land (tenants)) to landowners (those who own the propriety), to land managers (those who manage the land). Therefore in order to comprise all the heterogeneity existent, in this paper it was decided to use the designation land manager which include all the ones mentioned before since a land-manager can be an owner or tenant. The aim of this paper is therefore, to show how, in the multifunctional transition process going on in Mediterranean Europe, attitudes and behaviors of land managers are coherent or not with each other and how they interplay, revealing consistencies and gaps, and what explains or is related to the existing incoherences. The knowledge produced will help understand the on-going changes in farm landscapes, and it is thus expected to be useful in supporting the formulation of more targeted public interventions for the rural landscape management. The analysis is grounded on a case study in Southern Portugal, with a survey to 373 land managers, and the classification of attitudes and behaviors follows a productivist/non-productivist spectrum, leading to a typology of land managers.

\section{METHODOLOGY}

A relevant approach to analyse the heterogeneity in behaviors and attitudes of land managers is to formulate typologies (Daskalopoulou \& Petrou, 2002; Valbuena et al., 2008; van der Ploeg et al., 2009). A typology is a tool to simplify the diversity of land managers and their strategies (Valbuena et al., 2008). The variables and dimensions that should be analysed to construct a typology, depend on the goals we want to reach (Valbuena et al., 2008; Emtage \& Herbohn, 2012a). In this study was used a multivariate statistical analyses to identify a typology (Emtage \& Herbohn, 2012b) of attitudes and behaviors regarding the multifunctional transitional process that are happening in the Mediterranean rural areas. With the typology can be understood the capacity of innovation or adaptation of the different land managers and how they can contribute to the multifunctional transitions in place (Gilg, 
Barroso F., Pinto-Correia T.: Land managers' heterogeneity in Mediterranean landscapes - consistencies and contradictions between attitudes and behaviors.

2009). In order to analyse the land managers' diversity, three case-study areas in Alentejo (Southern Portugal) were studied (Figure 1). Alentejo is located in southern Portugal, its administrative organization comprising a set of 47 municipalities covering an area of 1,551 $\mathrm{km}^{2}$ representing a third of the area of the country (Fig. 1).

\section{Fig. 1: Three case-study areas studied in Alentejo}

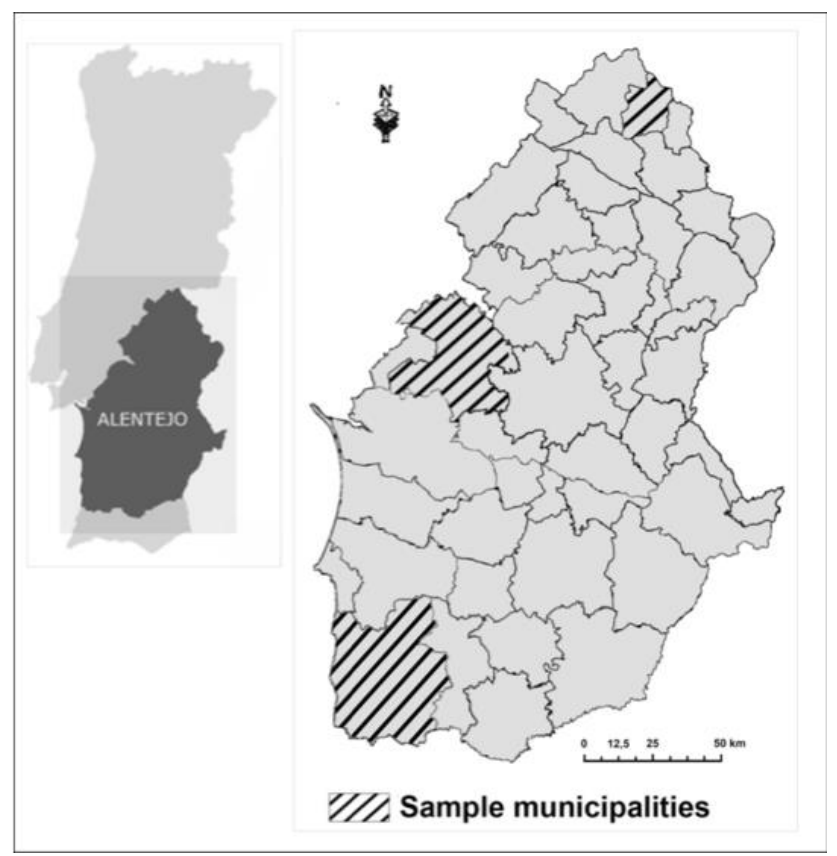

Although there are differences across the area, Alentejo is well known in Portugal for its characteristic rolling plains and flat land landscapes as well as by its dry Mediterranean climate. In addition Alentejo is also appreciated for its historical and cultural heritage concentrated in small to medium urban areas surrounded by a countryside landscape. Also in rural areas it is common that each small village or town centre holds ancient castles, churches or yet other heritage buildings. A prominent land cover class is the Montado agro-forestry system (Carvalho-Ribeiro et. al, 2013). Around town are small olive groves, vegetable gardens, orchards and vineyards. Thus the three areas of study were chosen since they are representative from Alentejo region and also because these areas are already highly demanded by the society for other services besides farming, as hunting, or eco-tourism. Were also chosen since these three municipalities comprise the most common land use types of Alentejo. To assess how the multifunctional transition process is occurring specifically in this Mediterranean context with all its specificities, multifunctional transition indicators were developed based on the productivism and non-productivism dimensions, according to Wilson (2007) and adapted to the context of this study through literature review and consultation of experts. A survey based on a questionnaire was undertaken in 373 sample of holdings. In this questionnaire, different questions reflecting the productivism and non-productivism dimensions referred above were defined. Questions were formulated in order to position and polarize land managers answers from productivism to non-productivism. Eighteen dimensions (white boxes - Figure 2) were developed under four 
main topics: Land Manager Profile; Attitudes-thoughts; Behaviors-actions and Holding. Each topic and dimension is described in the table below (Table1).

Fig. 2: Four main topics (light-grey boxes) and following eighteen dimensions (white boxes) developed in the land managers' questionnaire

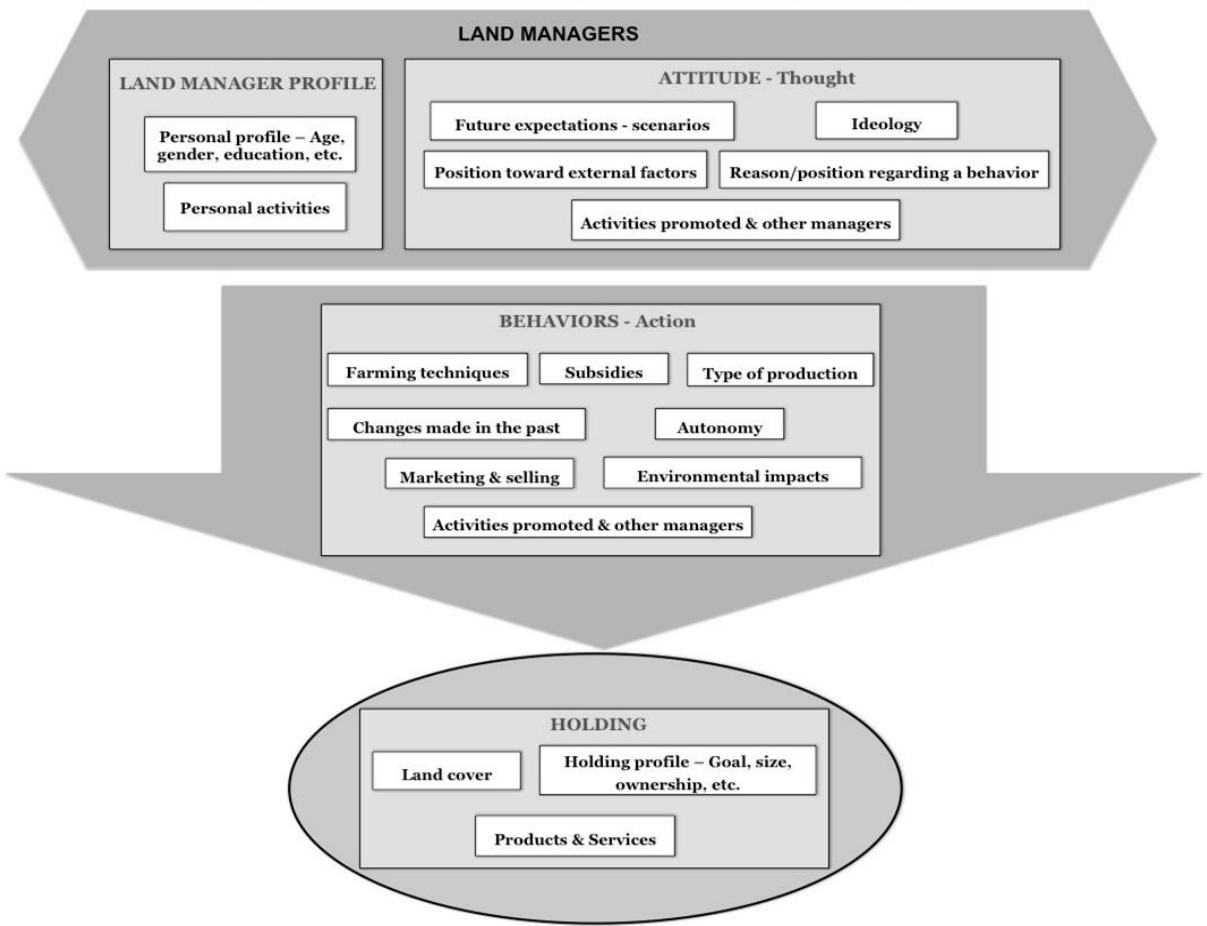

The sample was stratified by holding area and $n^{\circ}$ holdings per parish in each study area. For a universe of 2622 holdings in the three municipalities, 373 face-to-face questionnaires were made in order to be representative.

Basic statistics were employed for data analysis. In addition a multivariate analysis was made using the SPAD software (Version 3.2). The first step was a Multiple Correspondence Analyses (MCA), a factorial analysis that submits qualitative data to the process of the quantification and allows studying the relationship between two or more nominal variables (Greenacre \& Blasius, 2006). The MCA organizes all data in groups of characteristics and responses, being the active variables those who define the groups and the passive those that illustrate the profile of the group. The objective to separate the behaviours and attitudes was to classify land managers within a productivist and/or post productivist action and thought spectrum. Therefore, since active variables established the clusters, the active variables considered were: first, the answers to the questions related with the Attitudes-thoughts dimension and second, the answers to the questions related with the Behaviours-actions dimension. As passive, or explanatory, all other variables, both those related with the dimension Land managers profile and the Holding. Depending on the analysis, also the Attitudes-thoughts variables or the Behaviors-actions variables were included as passive or explanatory. 
Barroso F., Pinto-Correia T.: Land managers' heterogeneity in Mediterranean landscapes - consistencies and contradictions between attitudes and behaviors.

Table 1: Four main topics, dimensions of each topic and a small description

\begin{tabular}{|c|c|c|}
\hline Topics & Dimensions & Description \\
\hline \multirow[b]{2}{*}{$\begin{array}{l}\text { Land Manager } \\
\text { Profile }\end{array}$} & Personal Profile & $\begin{array}{l}\text { Socio-economical profile } \\
\text { (age, education, childhood, gender etc.) }\end{array}$ \\
\hline & Personal Activities & $\begin{array}{l}\text { Activities the land manager personally } \\
\text { does in the countryside (Horse-riding, } \\
\text { hunting, farming, mushroom-picking, } \\
\text { etc). }\end{array}$ \\
\hline \multirow{5}{*}{ Attitudes-thoughts } & Future expectation-scenarios & \multirow{5}{*}{$\begin{array}{l}\text { Thoughts, values, expectations, beliefs } \\
\text { and ideas. } \\
\text { What the land manager thinks, what are } \\
\text { their expectations about the future, how } \\
\text { was their position regarding: the } \\
\text { subsidies, the state, the social demand, } \\
\text { the environment, etc. }\end{array}$} \\
\hline & Ideology & \\
\hline & Position toward external factors & \\
\hline & $\begin{array}{c}\text { Reasons/position regarding a } \\
\text { behaviour }\end{array}$ & \\
\hline & $\begin{array}{l}\text { Activities Promoted \& other } \\
\text { land managers }\end{array}$ & \\
\hline \multirow{8}{*}{ Behaviours-actions } & Type of production & \multirow{8}{*}{$\begin{array}{l}\text { Practical issues or actions that the } \\
\text { manager decides for the holding } \\
\text { What the land manager does regarding } \\
\text { issues like: the chemical inputs; } \\
\text { technologies used; the holding history; } \\
\text { soil protection; autonomy; type of } \\
\text { subsidies; livestock production; } \\
\text { commercial- ization; activities in the } \\
\text { holding besides farming; other land } \\
\text { managers in the holding and the } \\
\text { autonomy degree of these land managers }\end{array}$} \\
\hline & Farming techniques & \\
\hline & Subsidies & \\
\hline & Autonomy & \\
\hline & Changes made in the past & \\
\hline & Marketing \& Selling & \\
\hline & Environmental impacts & \\
\hline & $\begin{array}{l}\text { Activities promoted \& other } \\
\text { land managers }\end{array}$ & \\
\hline \multirow{3}{*}{ Holding } & Land cover & \multirow{3}{*}{$\begin{array}{l}\text { Overview of the holding: holding size, } \\
\text { ownership, holding goal, outcomes of the } \\
\text { holding management, land-cover and } \\
\text { area occupied }\end{array}$} \\
\hline & Products \& services & \\
\hline & Holding profile & \\
\hline
\end{tabular}

Active variables with frequency less than $2 \%$ were eliminated to remove "noise" and strengthen the results. These variables became illustrative. Second, a number of factors that retain at least $50 \%$ of the total variance were picked: $45(51 \%)$ for attitudes and 20 for behavior (52\%). After the MCA two steps of the cluster analysis were made.

First a non-hierarchical, divisive, partitive clustering method using $k$-means, with three basic partitions with 10 classes each. Subsequently, on the center of gravity of the groups formed a ward's method which is an agglomerative, hierarchical, ascending clustering method was applied in order to join the groups and check the distance between them. For each cut level in the dendrogram, a consolidation was made in order to reallocate less defined individuals or sparser groups to a closer leg of the dendogram. The purpose of all this (MCA and cluster analysis) was to optimise the formation of groups of individuals: joining and separating individuals according to what is stronger on the information that characterizes them. What follows was a simple description of the modalities that are over-represented in the groups formed and ranked according to a statistical test (null hypothesis test). The Value-test when it is greater than 1.96 we can ensure with $95 \%$ confidence that the inclusion of the modality in the group is not casual. The higher the value, the stronger the importance of modality in the group. This was therefore a descriptive method that can be applied to any group of individuals. Since the groups consisting on a classification made on the strong factors of the MCA, their profiles directly reflect what is important in data structure and describe very well the hierarchy of factors (Lebart et. al., 1997). 
Regarding the position concerning the productivism/non-productivism spectrum, all the active variables were analysed through expert analysis. When the questions were formulated for the questionnaire, the alternatives for responses were polarized in order to understand more easily if the responses were going towards the productivism or non-productivism. The responses that are related with productivism were classified as minus 1 or minus 2 (if the value-test is greater then 5). The responses related with non-productivism, plus 1 or plus 2 (if the value-test is greater then 5). Neutral responses get 0 . In the end a sum of all the active variables was done and the type is positioned along a productivism/non-productivism spectrum (from strongly productivist until strongly non-productivist). The next step regarding the analysis was to cross the results between the attitudes and the behaviors types in order to understand how each type of behavior is linked with an attitude to understand which are the gaps and consistencies between them.

\section{RESULTS}

The overall characteristics of some the survey responses are presented in the tables below (Tab 2, Tab. 3, Tab. 4). Regarding the property area, the characteristics of the survey respondents were found to match with the official national statistics. In addition, the majority of the respondents have a low level of education (68\%); and just $33 \%$ have the high school or university degree. As expected the majority of the land managers are man (86\%). Only $8 \%$ are young land managers (less then 40 years), and $45 \%$ are between $41-65$ years old. Nevertheless a high rate of land managers are elderly (39\%). Regarding the main professional activity most of the land managers have a job connected with farming and rural activities $(64 \%)$, the other $36 \%$ came from other types of jobs not related with rural and farming. $46 \%$ of the respondents are dependent from income from outside of the holding activity.

Table 2: Socio-economic characteristics

\begin{tabular}{|c|c|c|c|c|c|c|c|}
\hline \multicolumn{2}{|c|}{ Gender (\%) } & \multicolumn{2}{c|}{ Age (\%) } & \multicolumn{2}{c|}{ Holding area (\%) } & \multicolumn{2}{c|}{ Education (\%) } \\
\hline Man & 86 & $15-24$ & 1 & $0-5$ ha & 29 & No schooling & 14 \\
\hline Women & 14 & $25-34$ & 3 & $5-50$ ha & 33 & primary education & 28 \\
\hline & & $35-39$ & 4 & $>50$ ha & 38 & Basic education & 26 \\
\hline & & $40-44$ & 7 & & & High school & 15 \\
\hline & & $45-54$ & 18 & & & University degree & 18 \\
\hline & & $55-64$ & 27 & & & & \\
\hline & & $>65$ & 39 & & & & \\
\hline
\end{tabular}

Table 3: Socio-economic characteristics

\begin{tabular}{|c|c|c|c|}
\hline \multicolumn{2}{|c|}{ Main professional activity (\%) } & \multicolumn{2}{c|}{ Family income (\%) } \\
\hline Farming/Livestock/Forestry & 39 & Farming activity & 32 \\
\hline Services linked to agriculture & 5 & Other farm activities & 2 \\
\hline Retired-Farming & 18 & From outside the farm & 46 \\
\hline Retired from other Jobs & 16 & From holding and outside & 20 \\
\hline Rural tourism manager & 2 & & \\
\hline Other Jobs & 20 & & \\
\hline
\end{tabular}


Barroso F., Pinto-Correia T.: Land managers' heterogeneity in Mediterranean landscapes - consistencies and contradictions between attitudes and behaviors.

\section{Table 4: Socio-economic characteristics}

\begin{tabular}{|c|c|c|c|}
\hline Weight (\%) of the subsidies in the total income (\%) & \multicolumn{2}{|c|}{ Holding acquisition (\%) } \\
\hline Low (<25\%) & 21 & Bought or inherited & 70 \\
\hline Medium-low (25-49\%) & 16 & Rented & 19 \\
\hline Medium-high (50-75\%) & 23 & Lended & 12 \\
\hline High (> 75\%) & 4 & & \\
\hline Without subsidies & 37 & & \\
\hline
\end{tabular}

Most of the holdings are bought or inherited. A significant rate (37\%) of the respondents don't have any subsidy - mainly small scale farmers. Most of the respondents (58\%), which are small-scale owners, sell almost all their production in the holding, or simply do not sell, but produce for themselves and their family

Regarding the multivariate analysis a lot of information was analysed. The active variables are those who define the different land managers types. From the first analysis regarding the attitudes-thoughts typology (Fig. 3) it can be seen that a first split in the dendogram is between the Risk-taking group and the Unadventurous. These two large groups continue to split, leading to eight types of land managers according the attitudes. Table 5 has a description of these groups, according to the most significant variables for each group.

Fig. 3: Results of multivariate analysis according with the Attitudes-thoughts dimension. Dendogram and consequent eight types of land managers attitudes

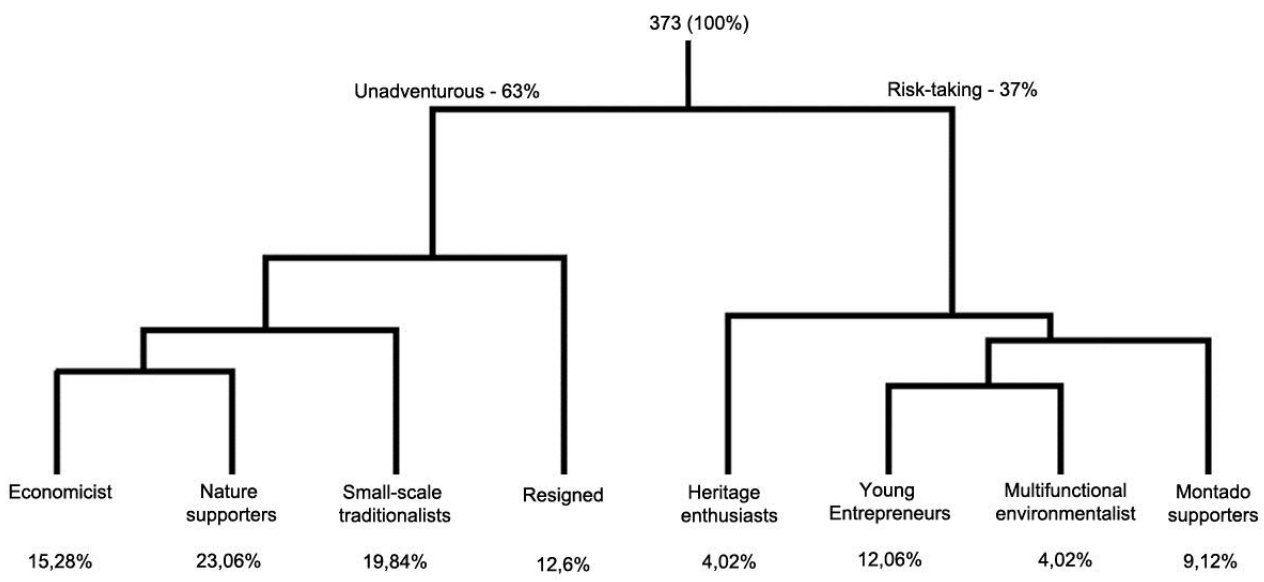




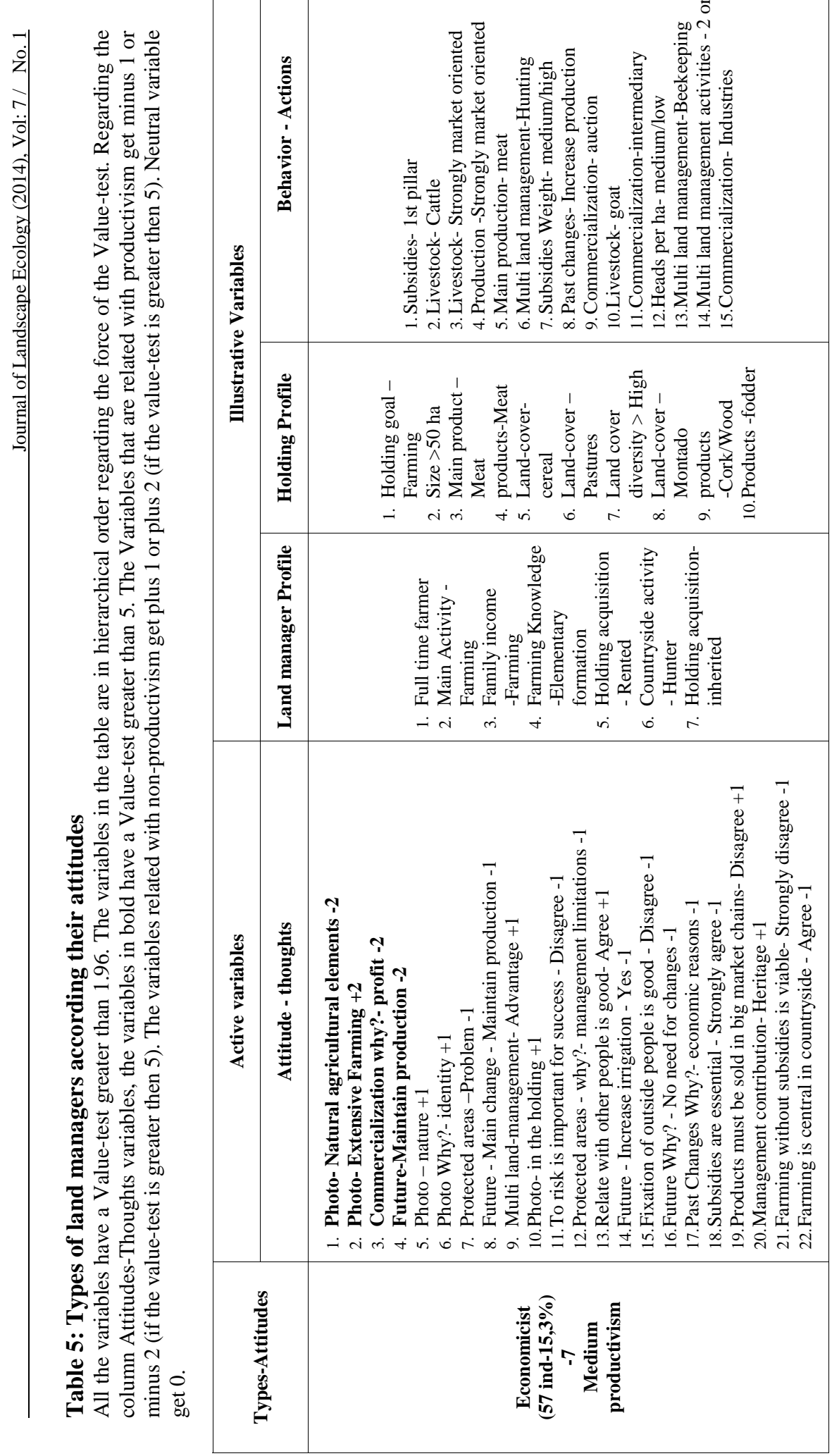




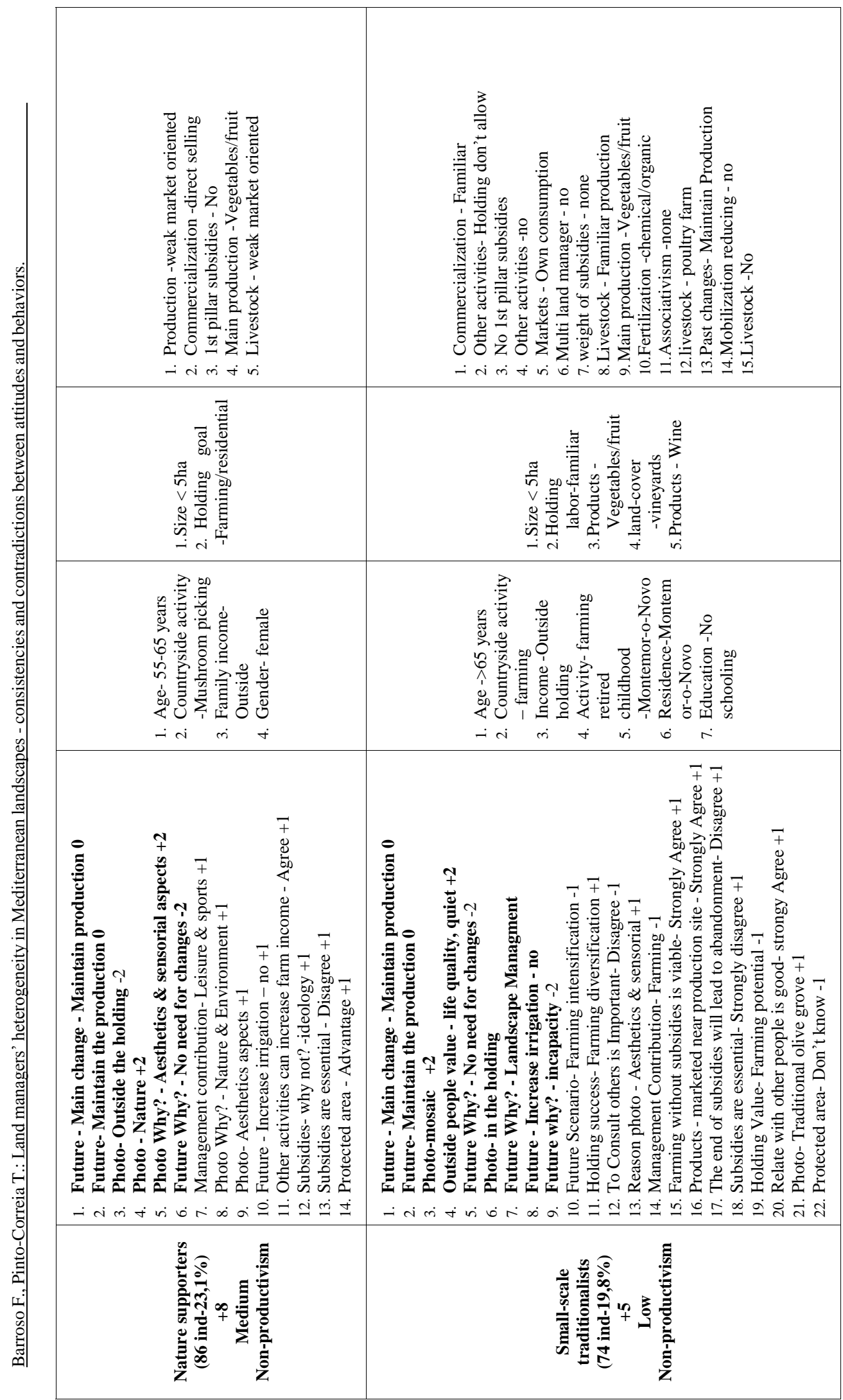




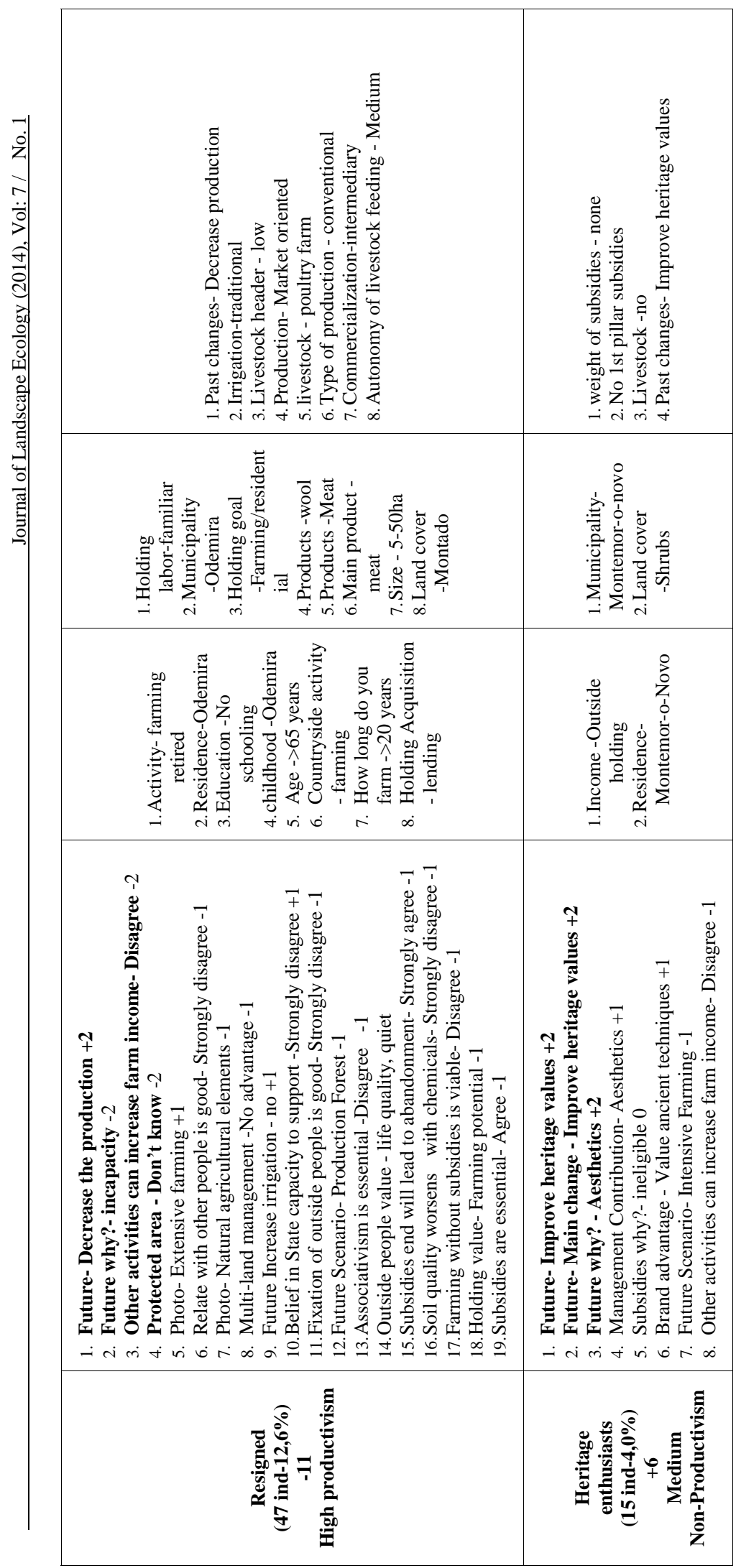




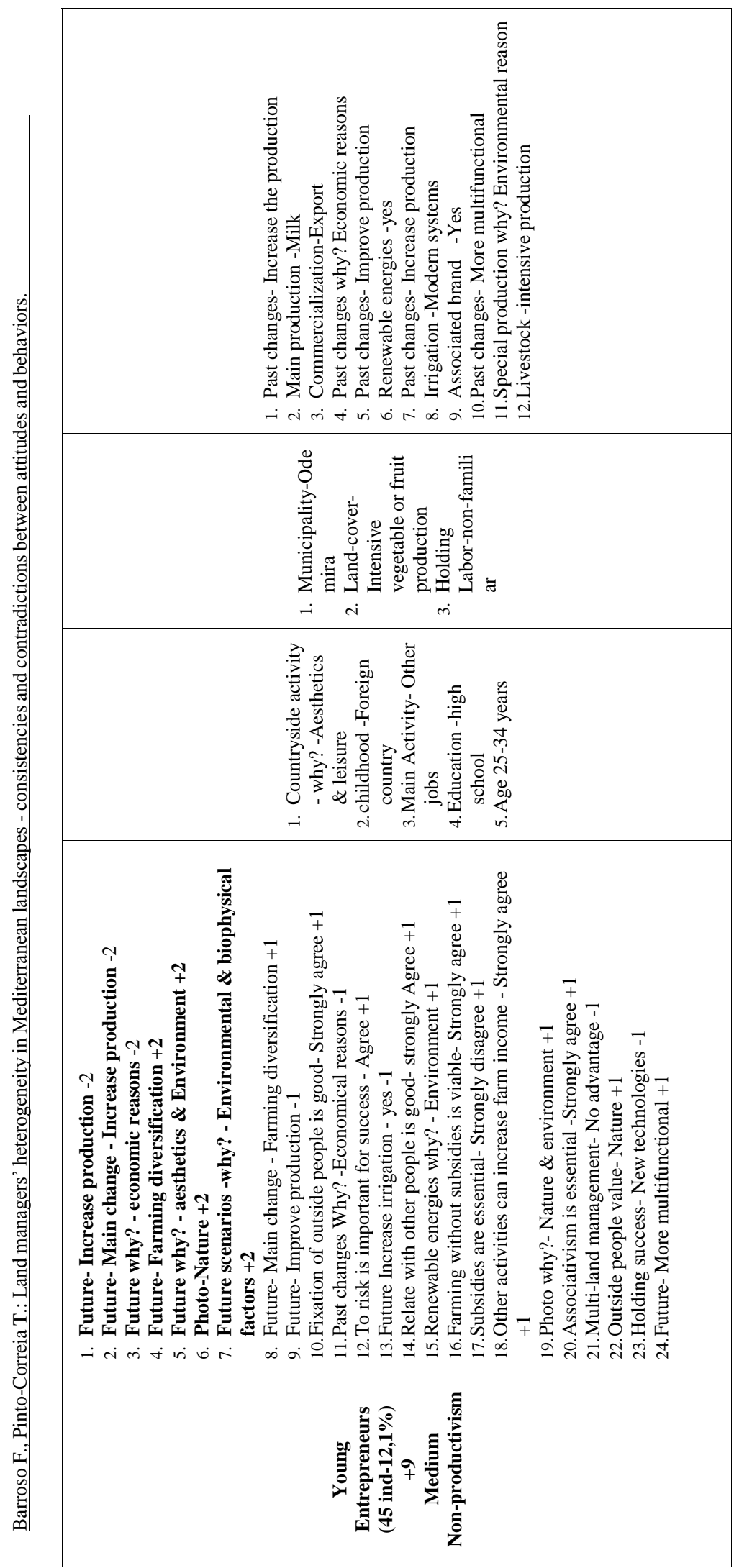




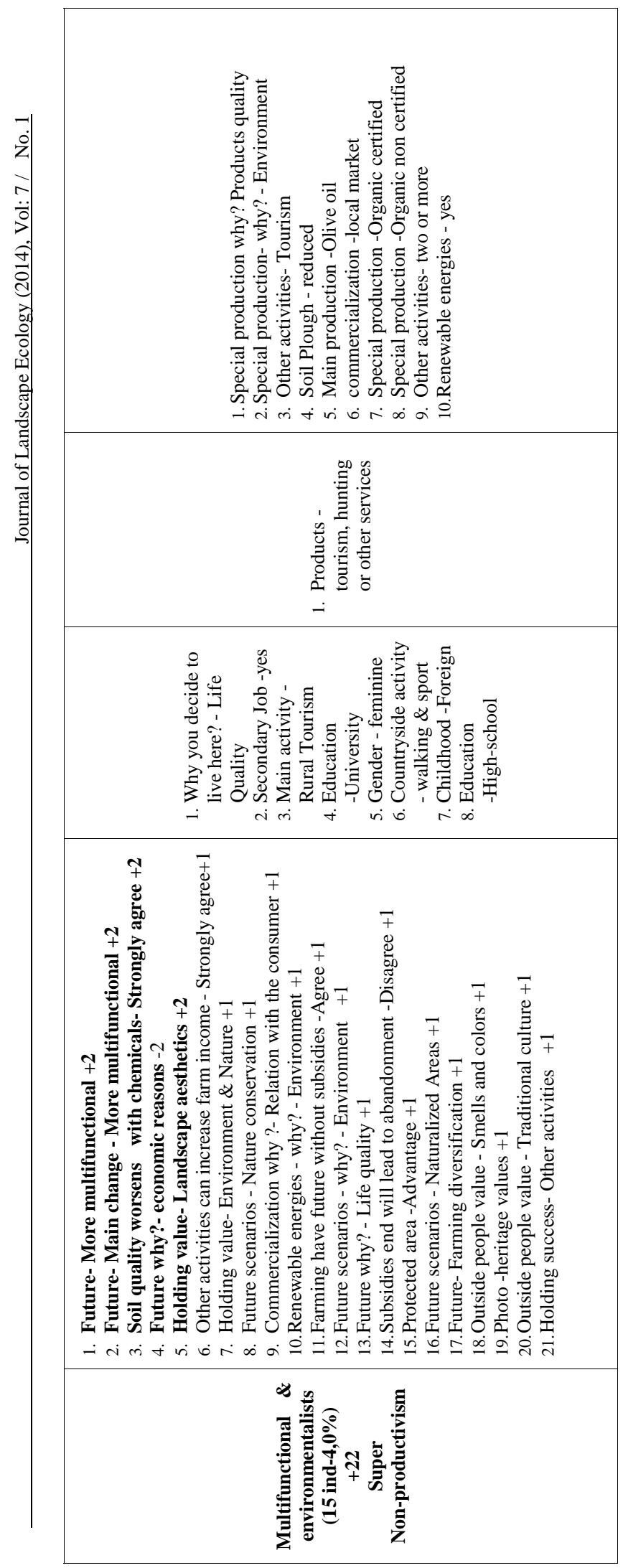

in 


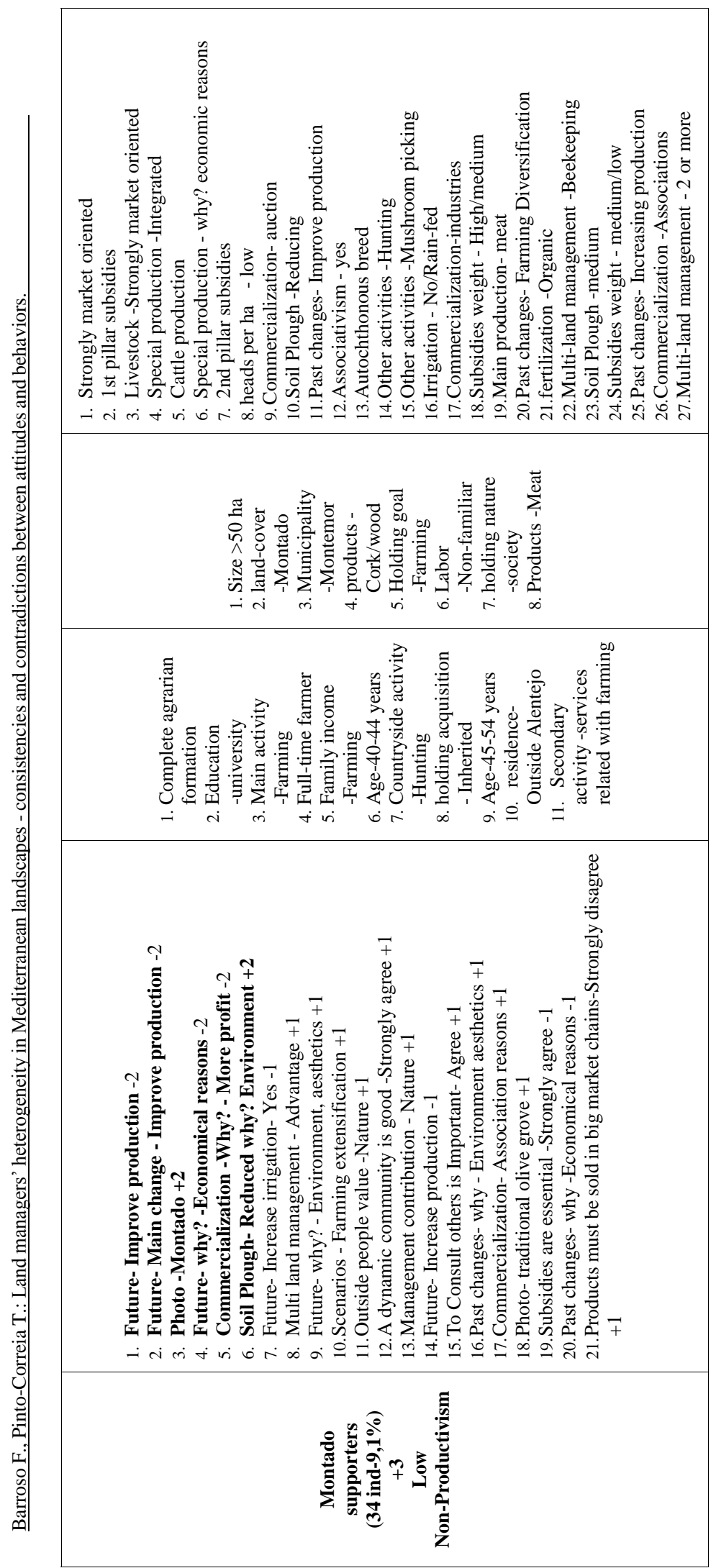


The eight groups have a clear distinction between them, and have clear separate positions in a spectrum from productivism to non-productivism. Further, the attitudes related with expectations about the future are the most significant, and consequently, more important to the definition of the types.

After the multivariate analysis made to the attitudes the same analysis was applied to the behaviors (Fig. 4). After making a more detailed and careful analysis to the Behaviors-actions dimension multivariate analysis, most groups have sufficient significant variables to assess and understand each group. At first glance it appears that a first split occurs between those who have livestock production and those who don't have. After the first split a second split occur in the livestock related group, between those who are market oriented and those who are not market oriented. In the end, several subdivisions occur and the result was eight different types of land managers according the Behaviors-action dimension. In the table below (table 6) is a description of each of eight behaviors types.

Fig. 4: Results of multivariate analysis according with the behaviors-action dimension. Dendogram and consequent eight types of land managers' behaviours

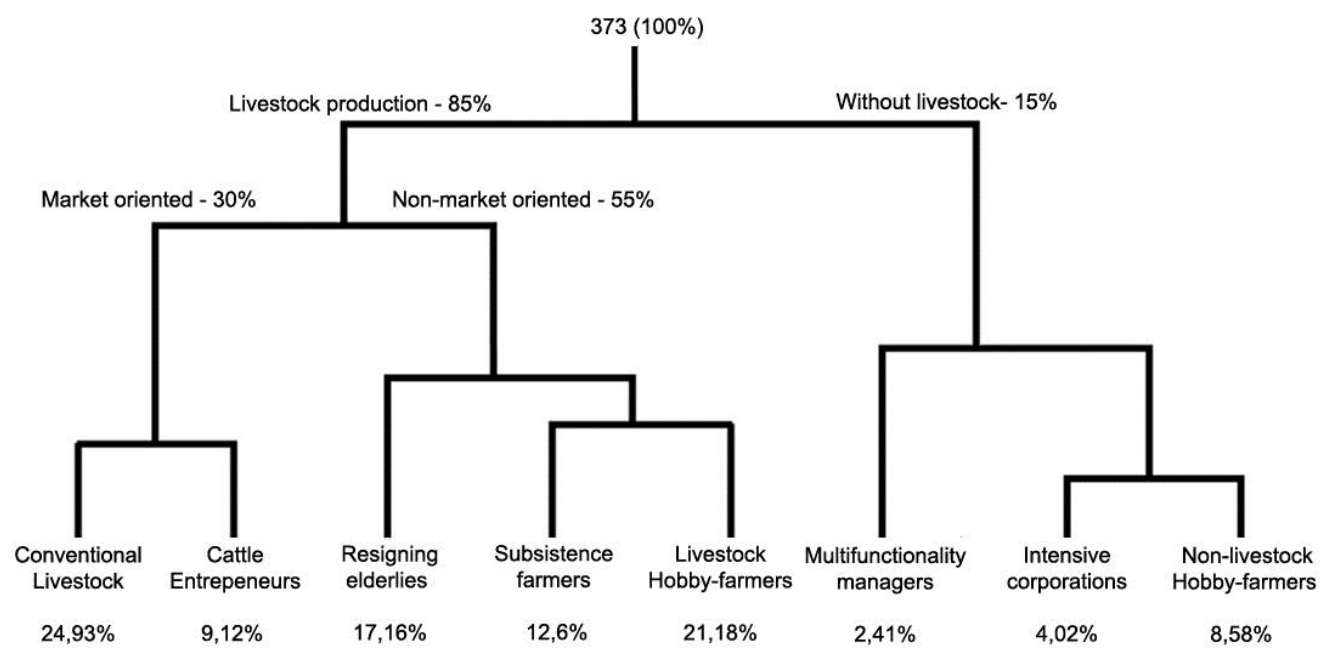




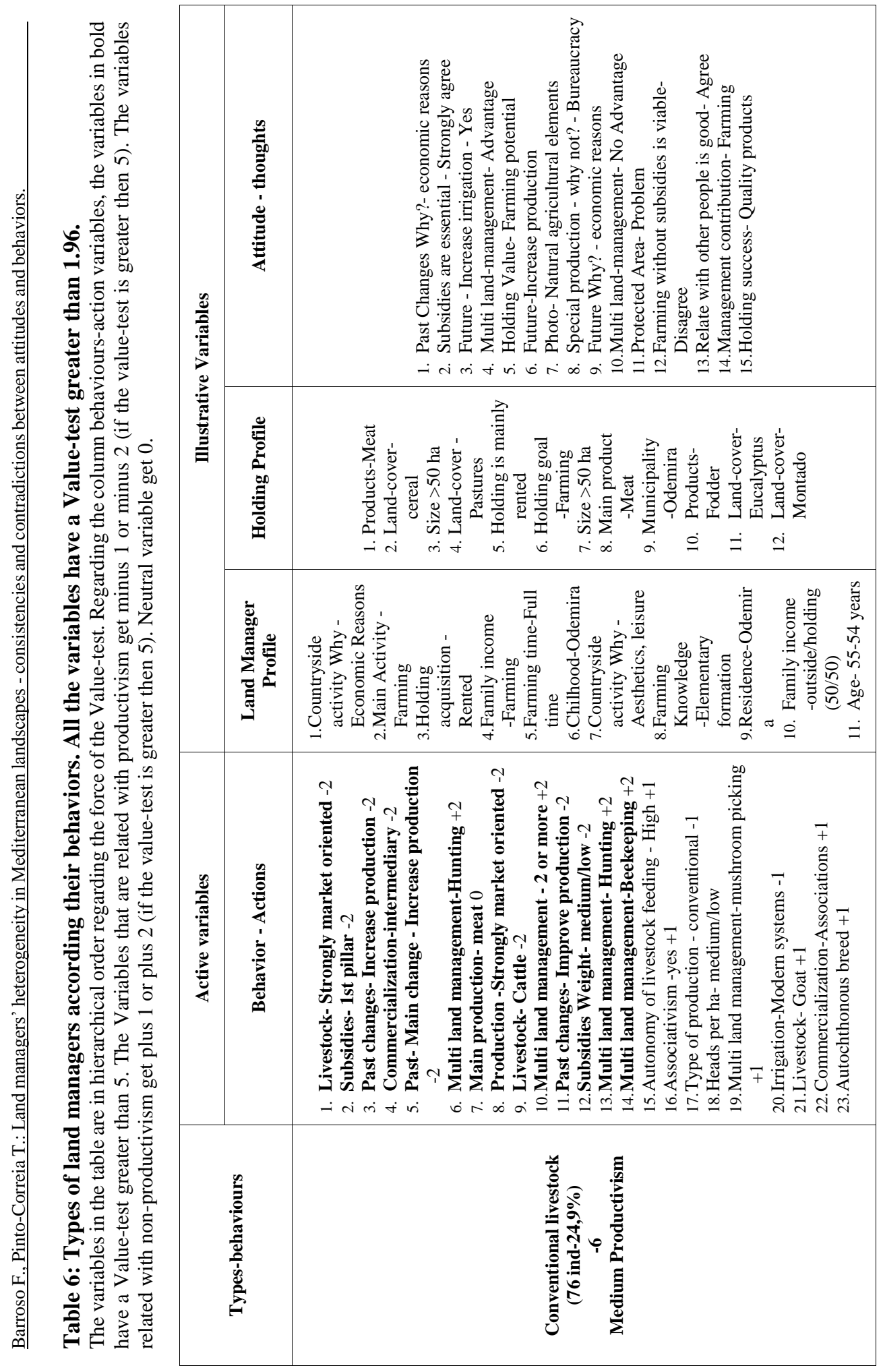




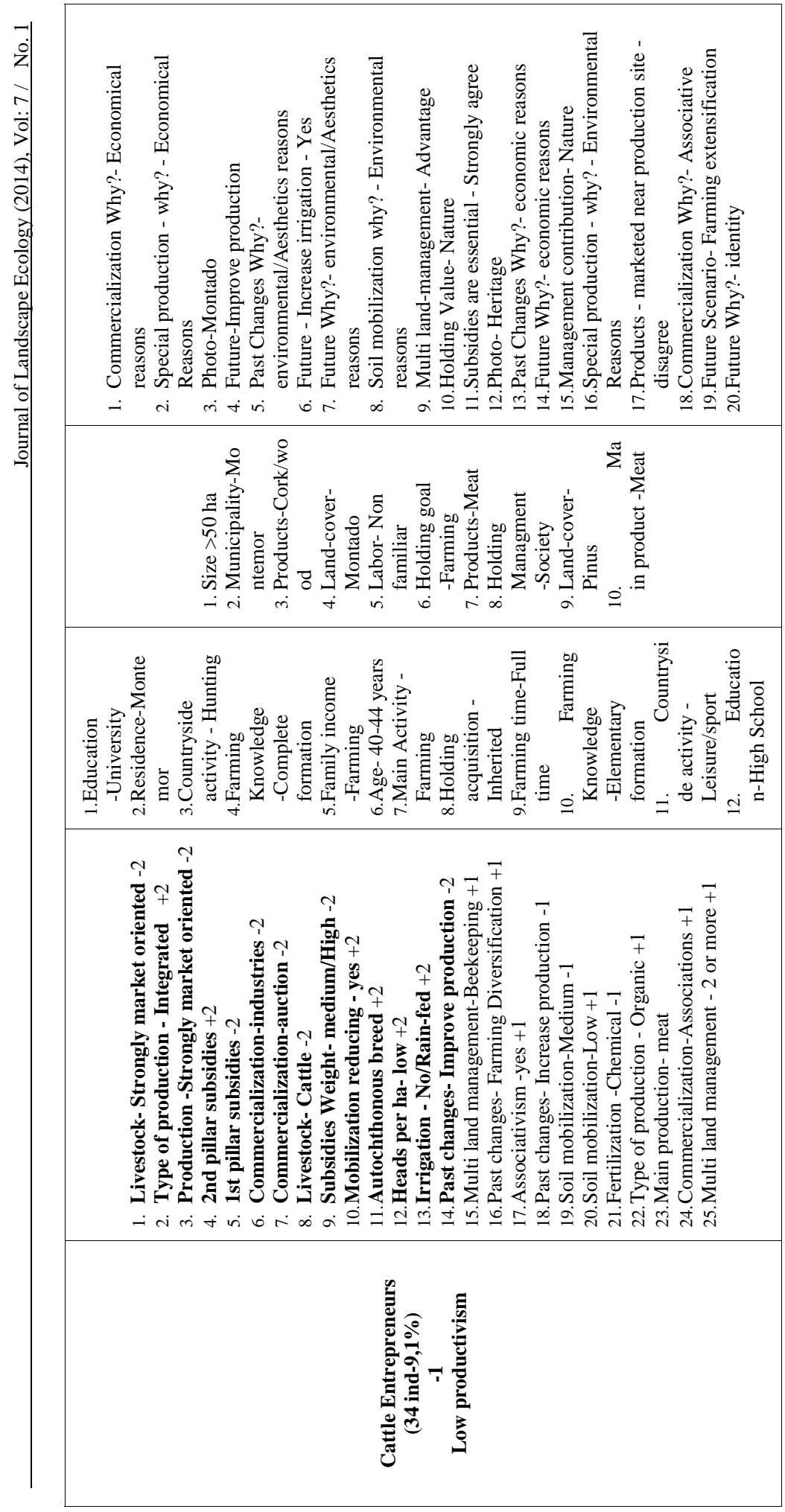




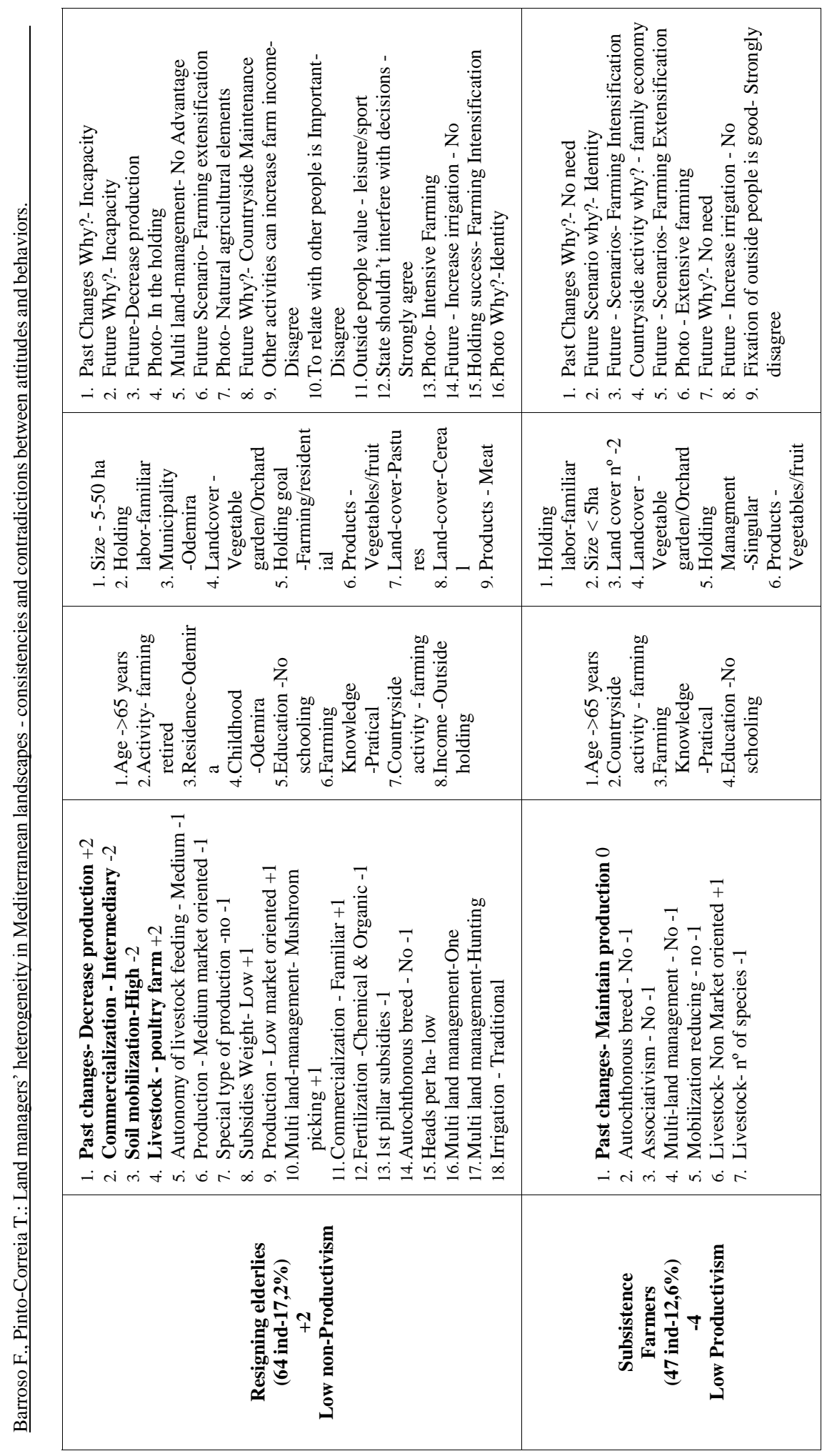




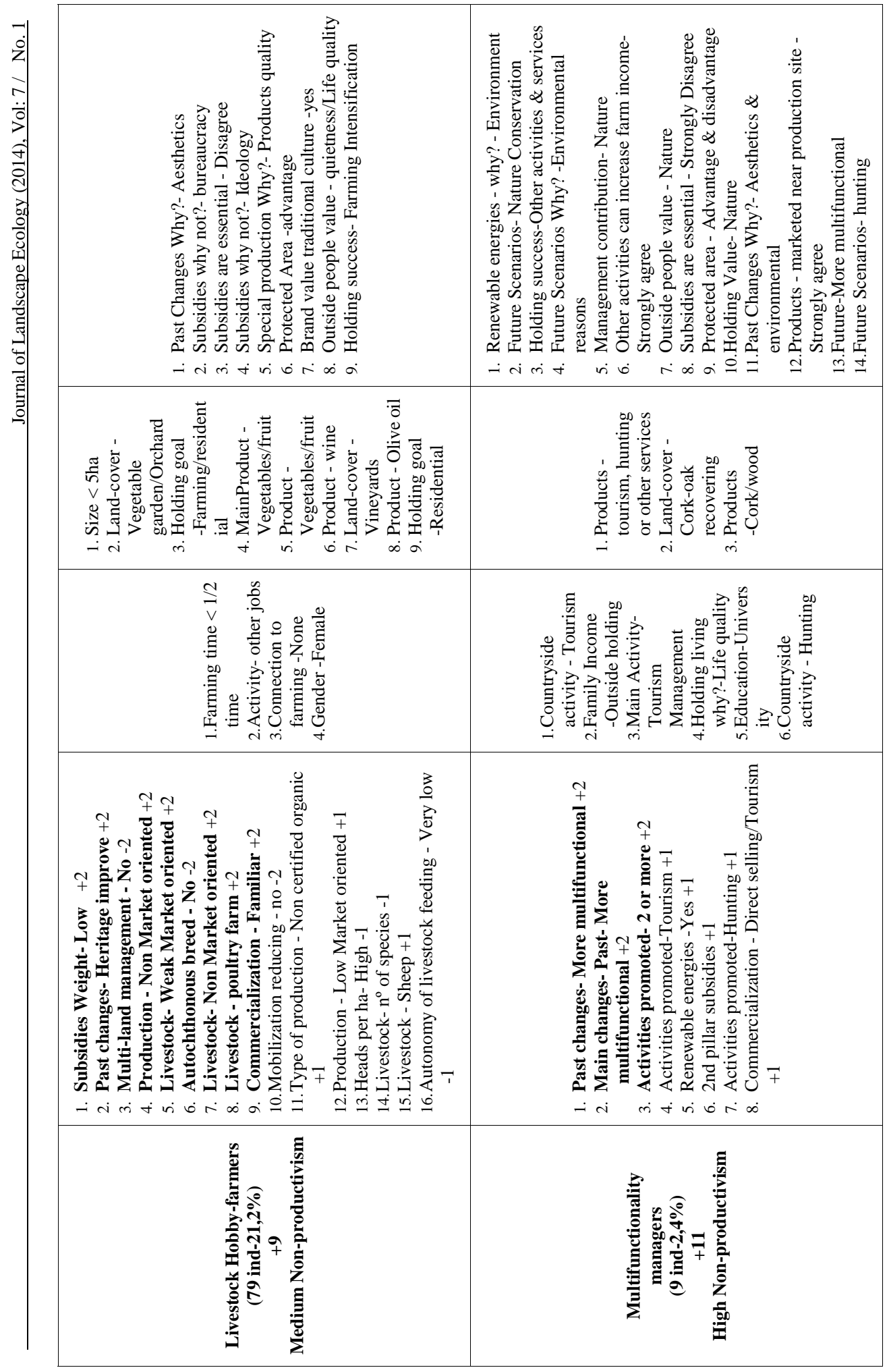




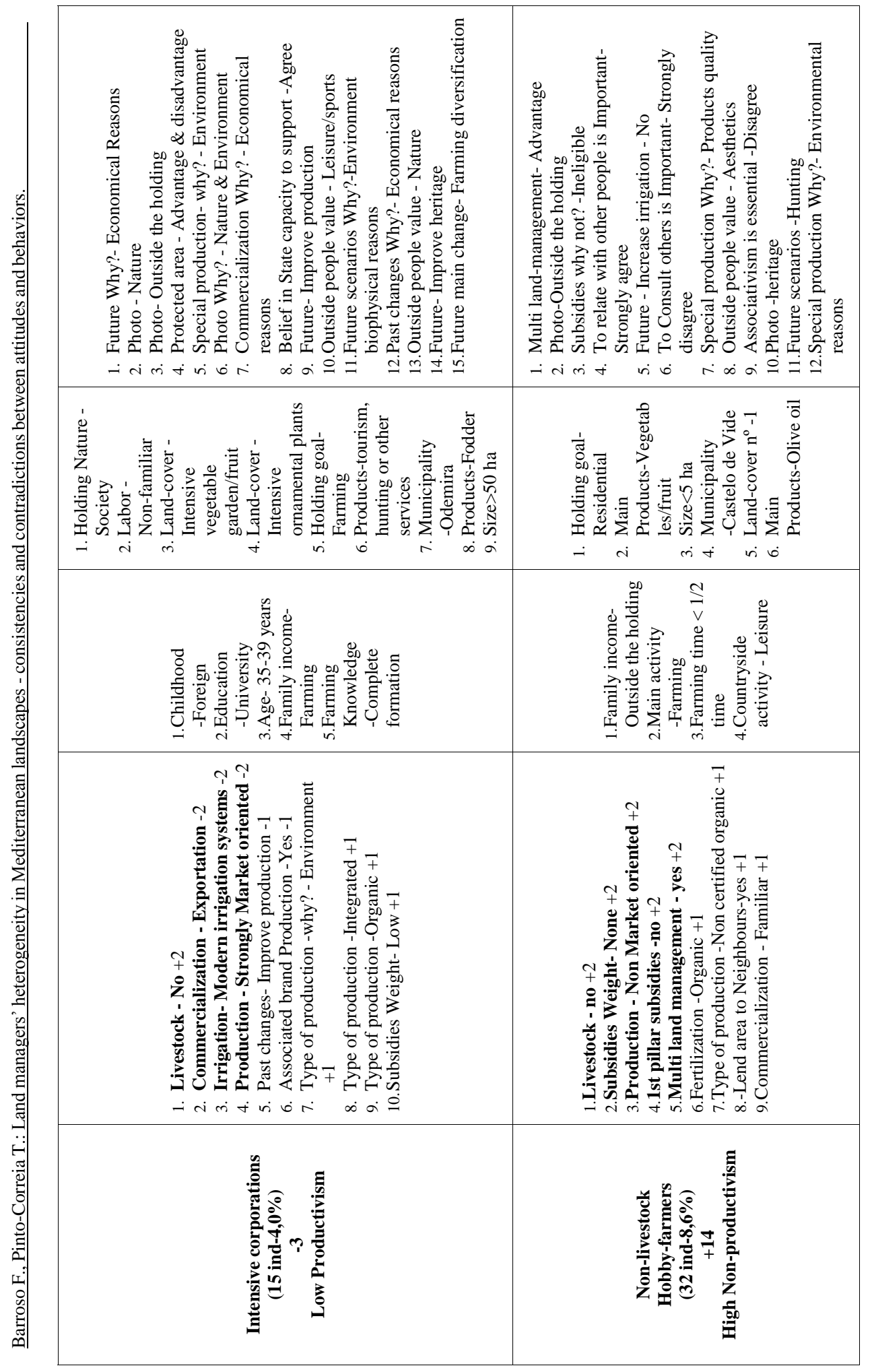


The eight groups have a clear distinction between them. From this table is possible to understand that there is almost an equal division between the non-productivist (49\%) and the productivist (51\%) types of behaviors.

When the attitudes and the behaviors types were crossed (Fig. 5) we can understand that some attitude types ( $\mathrm{X}$ axis) are strongly related with behaviors type (Y axis) and some others don't.

Fig. 5: Matrix resulting from the crossing between the land managers types according the behaviours-action dimension and the attitudes-action dimension

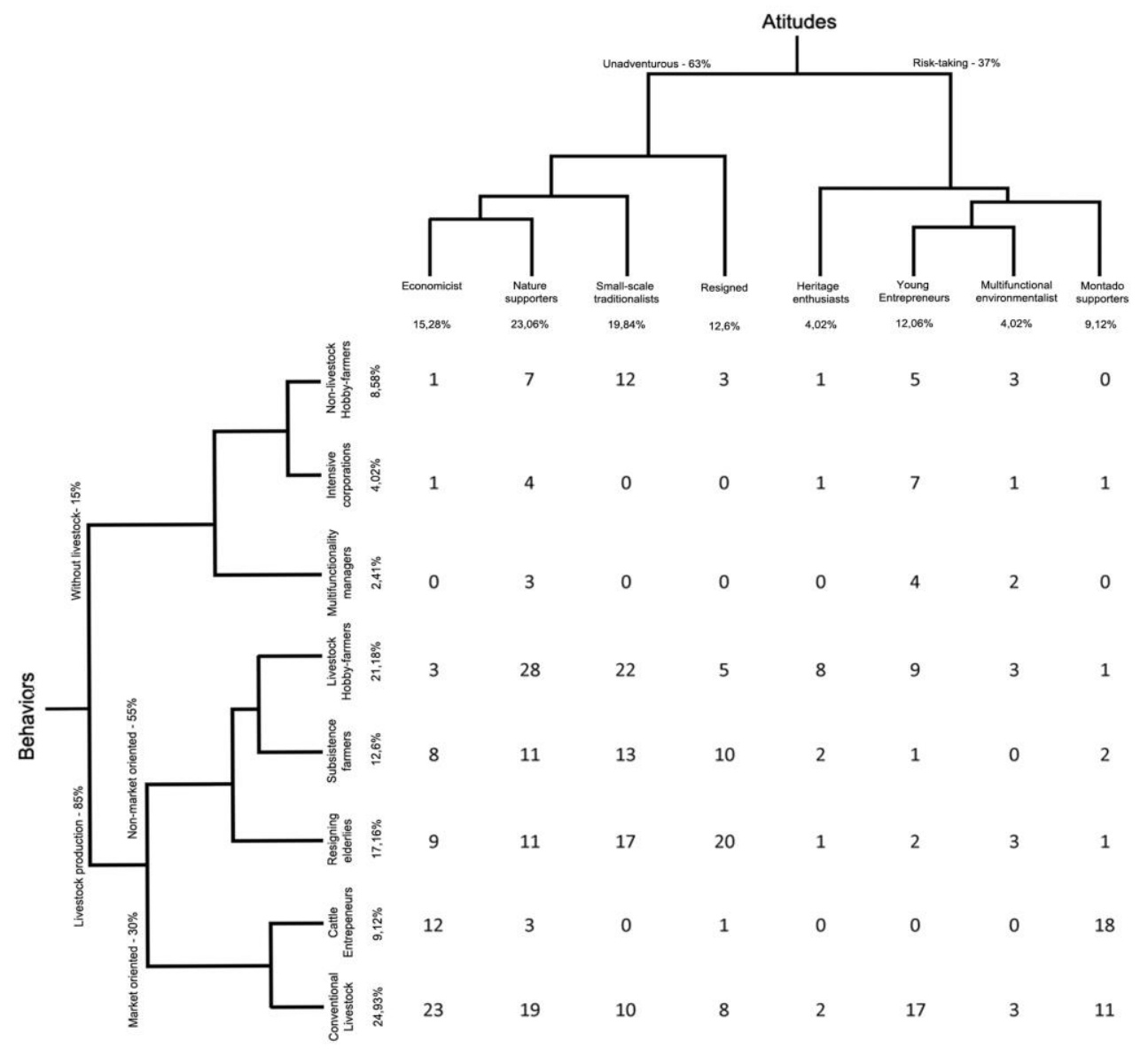

A new ordering of the attitudes and behaviors types was made: As the tables 5 and 6 show, an analysis for each type was made of the non-productivist and productivist variables, followed by a sum of all the active variables, in order to position each type in the productivism/non-productivism spectrum. The results of this analysis are in figure 6: some attitudes are in accordance with behaviors but some others are not. 
Barroso F., Pinto-Correia T.: Land managers' heterogeneity in Mediterranean landscapes - consistencies and contradictions between attitudes and behaviors.

Fig. 6: Position of each land manager type according the Attitudes-thoughts dimension and Behaviors-action dimension in multifunctional spectrum from Productivism to Non-productivism.

Each color corresponds to a certain degree of productivism or non-productivism. In the circles is the number of land managers belonging to cross between attitudes and behaviours type.

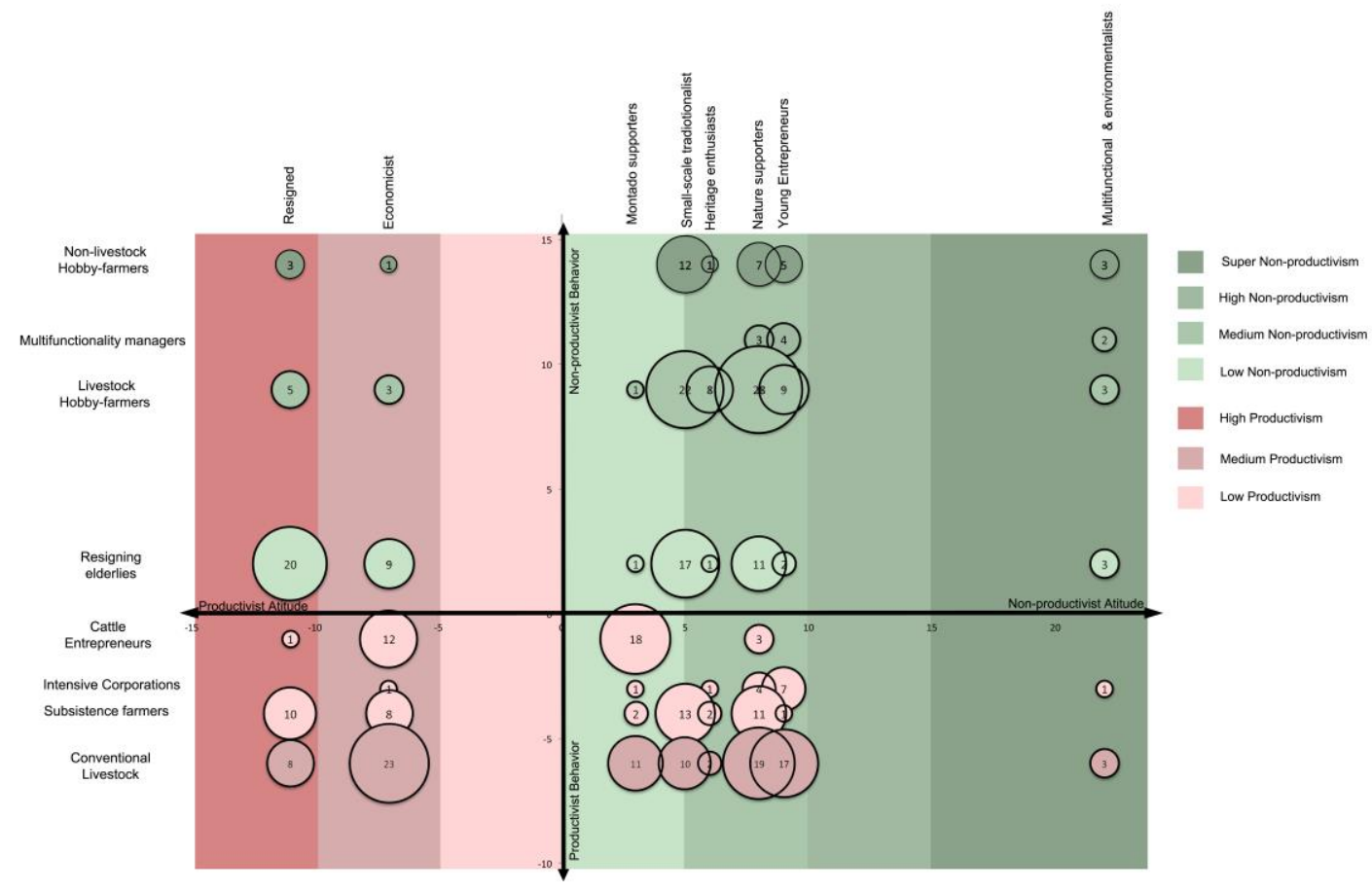

\section{DISCUSSION AND CONCLUSIONS}

The analysis undertaken has shown how the land managers types concept was very useful in understanding the heterogeneity regarding holding profile, attitudinal differences, different types of production and techniques and land managers profiles. Distinct farming types can be identified and classified with respect to attributes describing attitudes and the behaviours. Additionally, this analysis allowed comparing how land managers have some attitudes that could be linked to particular behaviour, and how those groups of behaviours and attitudes are positioned in a multifunctional spectrum. In some types of land managers attitude-behaviour consistency was high, but the analysis also suggests that we must be cautious in the use of attitudes as prime predictors for behaviour since in some cases the consistency between attitudes and behaviours were low (Steel, 1996; Lichtenberg \& Zimmerman, 1999; Selfa et al., 2008; Swanwick, 2009; Greiner et al., 2009). The results also show that different types of land managers are situated on different points of the productivist/non-productivist spectrum revealing as some authors stated (Wilson, 2001; Holmes, 2006; Burton \& Wilson, 2006) that productivism and non-productivism can occur simultaneously, spatially as well as temporally. It is also important to raise that land managers diversity also vary not just influenced by attitudes and behaviours but also influenced by social and economic status, childhood experience, particularly whether urban 
or rural, age, etc. (Swanwick, 2009). An important range of attitudes were studied, from risk aversion, will to innovate, environmental values, position towards legislation, pessimism, and satisfaction toward farming. Similarly several behaviours were also studied, as off-farm work, production, management, farm techniques, subsidies or other services (Willock et al., 1999).

At a broad level, it is possible to describe an oversimplified picture of a polarized land managers population regarding the attitudes-thoughts and behaviors-action dimensions. Regarding the attitudes, from the dendogram (Figure 3), the first division occurs between those who are more entrepreneur, more innovative (Risk-taking) and those that are the opposite (Unadventurous). Making a more in-deep analysis of these two groups it is possible to understand that at one extreme (Unadventurous) are the older, less affluent, less educated, less environmentally aware, less innovative, more pessimistic about the countryside and changes that may affect it. At the other extreme (Risk-taking) are younger land managers, with urban background, more affluent, who tend to be more innovative and entrepreneur, more autonomous, more prone to take some risk, with high interest in environmental matters, who are actively engaged with experiencing the countryside and more positive about changes that may affect it. Regarding the behaviours typology, there is a first separation (Figure 4) between those who have livestock production and those who don't. For those who have livestock production, the major product is meat, and cereal production is prominent in land cover mainly for animal feeding. This group is not so focused on other activities besides production. The second group is more related with non-productivism, more focused on multifunctionality and innovation. It is composed mainly by younger people with higher education level, more conscious towards the environment and nature. These findings may reflect the view in some literature, which argues that younger land managers with higher levels of formal education are more open to new ideas and diversification, more willing to invest in pollution reduction (Schmitzberger et al., 2005) and more likely adopt new technologies and management practices (Selfa et al., 2008). In opposition older farmers, with lower education level tend to have more traditional notions of farming and agriculture and may, therefore, be more productivist than their younger counterparts (Burton \& Wilson, 2006). Since in this study $66 \%$ of land managers are older than 55 years, that may be one of the explanations why productivist behaviors currently tends to predominate. Moreover the results regarding attitudes also show that $63 \%$ of the land managers are risk-averse (Unadventurous) which is also in accordance with some literature that suggest that land managers in general are risk averse and slow to accept. Additionally results show that the attitudes related with the future and land managers expectations are the ones more significant and consequently, more important to the definition of attitudes types. Therefore the risk-taking types of land managers who are more concerned about their future and with more expectations, are more self-motivated and goal oriented (Willock et al., 1999). Thus attitudes toward risk, innovation, expectation and the future seem to be of major importance in the study of decision-making of land managers. It seems also that the Risk-taking group is more related with the multifunctionality and non-productivism. The unadventurous group seems to be quite the opposite as they valorize more intensive farming.

Regarding behaviors, besides the livestock, issues related with the subsidies, type of production (organic or other) and market orientation seem to be the most relevant. Several splits (Figure 6) occur, between those who have a large scale production with large properties, and where the intensive farming has a prominent place, and those with small scale farming, which do not receive subsidies, and are not market oriented, and can be hobby or subsistence farming. This dichotomy between the large-scale holdings and the small scale is very typical from these Mediterranean areas (Pinto-Correia et al., 2013; Ortiz-Miranda et al., 
Barroso F., Pinto-Correia T.: Land managers' heterogeneity in Mediterranean landscapes - consistencies and contradictions between attitudes and behaviors.

2013). The structure of the holding business may reflect lifestyle objectives (Willock et al., 1999); for example large scale holdings usually are more market oriented, more dependent from the subsidies and tend to be a little more concerned with economic values (e.g. Cattle entrepreneurs, Conventional livestock or Intensive Corporations), while small scale land managers tend to be more independent from subsidies, and since they are not market oriented and not dependent from the holding income, they can afford to struggle for a more independent lifestyle (e.g. Non-livestock hobby farmers, Livestock hobby farmers, Resigning elderlies or subsistence farmers).

Six types have a non-productivist attitude $(72,2 \%)$ and just two have a productivist attitude $(27,8 \%)$. In behaviors, there is an almost equal division between the non-productivist (49\%) and the productivist $(51 \%)$ behaviors. This reveals that although land managers attitudes seem to show signs of what could be interpreted as non-productivism, a high number still act as someone who, first and foremost, continue to maximize food production and, as in other businesses, aims for profit (Willock et al., 1999). These results highlighted that there are substantial inconsistencies in the transition processes going on, and that there is no clear transition towards non-productivist (Wilson, 2001), once regarding the behaviors a change towards non-productivism is not obvious. Nevertheless substantial shifts toward non-productivist action and thought are to be expected in the next few decades, as new generations of land managers more solidly embedded in non-productivist action and thought are settling in these Mediterranean rural areas (Ortiz-Miranda et al., 2013). Differences between attitude and actual behavior have been repeatedly mentioned (e.g. Kaltenborn \& Bjerke, 2002; Selfa et al., 2008; Elen et al., 2013; Pinto-Correia et al., 2013), and this study is an example of it. An example of this inconsistency, already described in literature (Rodrigo \& Veiga, 2009; Pinto Correia et al., 2013) is the low non-productivist Montado supporters attitude, which strongly express their support for the traditional system, revealing an attitude of protection towards the Montado system, however some of their actions (low productivist Cattle entrepreneurs behavior) are mainly focused on intensification by increasing cattle grazing density or the artificialization of the system. Another example is the medium non-productivist Young entrepeneurs attitude characterized by a strong will towards sustainability and multifunctionality by adapting for example renewable energies and diversifying their production, but at the same time acting as Conventional Livestock behavior (strong productivism), intensifying cattle production. As some authors suggest profit motives are often stronger than environmental motives, therefore in the end the profit maximization may determine which type of actions will be adopted (Bougherara et al., 2009; Plieninger et al., 2004; Morris \& Potter, 1995; Willock et al., 1999). Besides this type of inconsistency another occurs even if between a much smaller number of land managers, who reveal a productivist attitude and non-productivist behaviour, what is unusual and seems to be very particular from Mediterranean countries (Pinto-Correia et al., 2013). Land managers reveal through their attitudes a will for being more production oriented, but they keep a multifunctional and sustainable system, probably due to the biophysical constrains where intensification is impossible, lack of entrepreneurship and the prevailing property structure (Bruckmeier \& Tovey, 2009; Rodrigo \& Veiga, 2009; Pinto correia et. al, 2013). An example of this inconsistency is the strong productivist Resigned attitude that is very much correlated with the low non-productivist Resigning elderlies behavior, and coincides with some observation that many farmers are initially not aware of the ecological values they have on their land (Schmitzberger et al., 2005).

It is most surprising in the present case study, that only $27,8 \%$ of land managers expressed a productivist attitude, since as previously mentioned, the literature regarding the transitions in the Mediterranean rural areas often states that productivist thinking still prevails unlike 
what happens in other parts of northern Europe (Wilson, 2001; Pinto correia et. al, 2010; Pinto correia et. al, 2013). A possible explanation can be that also in Southern Europe the non-productivist thoughts have been gaining attention, following influences from debates at the European level. The fragility of the Montado and the need to preserve its balance, highly debated in Portugal lately, may also have increased land managers awareness and therefore their intended care for the system (Pinto-Correia \& Godinho, 2013). Another explanation is surely related with the heterodoxy of Mediterranean agriculture and thus the multiple possible profiles of land managers in this region (Ortiz-Miranda et al., 2013).

Besides attitudes other factors as childhood experience, particularly if is an urban background or not, the age, the level of education, may have a key influence of the behaviors (Richards \& van der Ark, 2013; Damianos \& Skuras, 1996; Marcellini et al., 2007; Luzar \& Diagne, 1999; Swanwick, 2009; Kaltenborn \& Bjerke, 2002; Selfa et al., 2008). Furthermore, the results also show inconsistencies at the spatial level as productivist action and thought can co-exist alongside non-productivist patterns (Burton \& Wilson, 2006; Marsden \& Sonnino, 2008; Herzfeld \& Jongeneel, 2012). The results also show that some types of behaviors and attitudes are related with some particular areas. For example regarding the behaviors, the Intensive Corporations, the Resigning elderlies and the Conventional livestock are related with Odemira municipality. The Cattle entrepreneurs are related with Montemor-o-Novo and the Non Livestock Hobby-farmers with Castelo de Vide. Regarding the Attitudes the Montado Supporters, Heritage enthusiasts and the small scale traditionalists are related with Montemor-o-Novo. The Resigned and the Young entrepreneurs are related with Odemira and the Multifunctional \& environmentalists are related with foreign people. Therefore some types have some spatial correlation and therefore in the future this can be analysed more in deep, in order to understand which landscapes are more in risk and which are more resilient.

Land managers exhibit complex, multiple and sometimes contradictory attitudes and behaviors. The analysis undertaken makes it clear that the sole assessment of behaviors, or the understanding of attitudes, will not make a complete picture of how land managers are acting, and what are the options they will take, in face of multiple options. The complex combination of attitudes and behaviors, thought and action, brings us closer to understand what may be the tensions and conflicts that underlie in land managers decisions - and thus better assess how management options will be taken. In order to grasp what will be impacts in the landscape pattern, for a careful and targeted public intervention, this knowledge is needed. In particular, when dealing with the management of Mediterranean landscapes, where farm systems are complex and the land managers group particularly heterodox.

\section{ACKNOWLEDGMENTS}

This study benefited from the financial support of the Portuguese Foundation for Science and Technology through the PTDC/CS-GEO/110944/2009 project. Filipe Barroso holds a FCT doctoral grant (SFRH/BD/69095/2010).

\section{REFERENCES}

Baudry, J. \& Thenail, C., (2004). Interaction between farming systems, riparian zones, and landscape patterns: a case study in western France. Landscape and Urban Planning 67, 121129. 
Barroso F., Pinto-Correia T.: Land managers' heterogeneity in Mediterranean landscapes - consistencies and contradictions between attitudes and behaviors.

Bjørkhaug, H. \& Richards, C.A., (2008). Multifunctional agriculture in policy and practice? A comparative analysis of Norway and Australia. Journal of Rural Studies, 24, 98-111.

Blekesaune, A., Haugen, M.S. \& Villa, M., (2010). Dreaming of a Smallholding. Sociologia Ruralis, 50(3), 225-241.

Bougherara, D., Grolleau, G. \& Mzoughi, N., (2009). Buy local, pollute less: What drives households to join a community supported farm? Ecological Economics, 68(5), 1488-1495.

Burton, R.J.F. \& Wilson, G.A., (2006). Injecting social psychology theory into conceptualisations of agricultural agency: Towards a post-productivist farmer self-identity? Journal of Rural Studies, 22, 95-115.

Bruckmeier, K., \& Tovey, H.,. (2009). Rural sustainable development in the knowledge society. England: Ashgate.

Carvalho-Ribeiro, S., Ramos, I.L., Madeira, L., Barroso, F., Menezes, H, \& Pinto-Correia, T., (2013). Is land cover an important asset for addressing the subjectivelandscape dimensions? Land Use Policy 35, 50- 60.

Damianos, D. \& Skuras, D., (1996). Farm Business and the Development of Alternative Farm Enterprises : an Empirical Analysis in Greece. Journal of Rural Studies, 12(3), 273 283.

Daskalopoulou, I. \& Petrou, A., (2002). Utilising a farm typology to identify potential adopters of alternative farming activities in Greek agriculture. Journal of Rural Studies 18, 95-103.

Emtage, N. \& Herbohn, J., (2012a). Assessing rural land managers diversity in the Wet Tropics region of Queensland, Australia in relation to natural resource management programs: A market segmentation approach. Agricultural Systems, 110, 107-118.

Emtage, N. \& Herbohn, J., (2012b). Implications of land managers management goals, use of information and trust of others for the adoption of recommended practices in the Wet Tropics region of Australia. Landscape and Urban Planning, 107(4), 351-360.

Elands, B. \& Praestholm, S., (2008). Landowners' perspectives on the rural future and the role of forests across Europe. Journal of Rural Studies, 24, 72-85.

Elen, M., D’Heer, E. , Geuens, M. \& Vermeir, I., (2013). The influence of mood on attitudebehavior consistency. Journal of Business Research 66, 917-923.

Gilg, A., (2009). Perceptions about land use. Land Use Policy, 26, S76-S82.

Greenacre, M. J., \& Blasius, J., (2006). Multiple correspondence analysis and related methods. Boca-Raton, FL: Chapman-Hall.

Greiner, R., Patterson, L. \& Miller, O., (2009). Motivations, risk perceptions and adoption of conservation practices by farmers. Agricultural Systems 99, 86-104.

Guillem, E.E., Barnes, A.P., Rounsevell, M.D.A., \& Renwick, A., (2012). Refining perception-based farmer typologies with the analysis of past census data. Journal of Environmental Management, 110, 226-235.

Halfacree, K., (2007). Trial by space for a "radical rural": Introducing alternative localities, representations and lives. Journal of Rural Studies, 23(2), 125-141.

Holmes, J., (2006). Impulses towards a multifunctional transition in rural Australia: Gaps in the research agenda. Journal of Rural Studies 22, 142-160. 
Herzfeld, T. \& Jongeneel, R., (2012). Why do farmers behave as they do? Understanding compliance with rural, agricultural, and food attribute standards. Land Use Policy 29, 250 260.

Jack, 1., (2007). Accounting, post-productivism and corporate power in UK food and agriculture. Critical Perspectives on Accounting. 18, 905-931.

Kaltenborn, B.P. \& Bjerke, T., (2002). Association between environmental value orientations and landscape preferences. Landscape and Urban Planning, 59(1), 1-11.

Korf, B. \& Oughton, E., (2006). Rethinking the European countryside - can we learn from the South? Journal of Rural Studies, 22(3), 278-289.

Lebart, L., Morineau, A., Piron, M., (1997). Statistique exploratoire multidimensionelle. Dunod, Paris ,

Lichtenberg, E. \& Zimmerman, R., (1999). Information and farmers' attitudes about pesticides, water quality, and related environmental effects. Agriculture, Ecosystems and Environment, 73, 227-236

Luzar, E.J. \& Diagne, A., (1999). Participation in the next generation of agriculture conservation programs: the role of environmental attitudes. The Journal of Socio-Economics, 28(3), 335-349.

MacDonald, D., Crabtree, J.R., Wiesinger, G., Dax, T., Stamou, N., Fleury, P., Gutier- rez Lazpita, J. \& Gibon, A., (2000). Agricultural abandonment in mountain areas of Europe: environmental consequences and policy response. Journal of Environmental Management, 59, 47-69.

Mather, A.S.H., Hill, G. \& Nijnik, M. (2006). Post-productivism and rural land use: cul de sac or challenge for theorization? Journal of Rural Studies 22, 441-455.

Marcellini, F., Giuli,C. \& Gagliardi, C., Papa, P., (2007). Aging in Italy: urban-rural differences. Archives of gerontology and geriatrics, 44(3), 243-60.

Maye, D., Ilbery, B. \& Watts, D., (2009). Farm diversification, tenancy and CAP reform: Results from a survey of tenant farmers in England. Journal of Rural Studies, 25(3), 333 342.

Morris, C. \& Evans, N., (2004). Agricultural turns, geographical turns: retrospect and prospect. Journal of Rural Studies, 20(1), 95-111.

Morris, C. \& Potter, C., (1995). Recruiting the new conservationists: Farmers' adoption of agri-environmental schemes in the U.K. Journal of Rural Studies, 11(1), 51-63.

Marsden, T., (2011). From post-productionism to reflexive governance: Contested transitions in securing more sustainable food futures. Journal of Rural Studies 29, 123-134.

Marsden, T., \& Sonnino, R., (2008). Rural development and the regional state: Denying the multifunctional agriculture in the UK. Journal of Rural Studies, 24, 422-431.

Naveh, Z. \& Lieberman, A., (1994). Landscape ecology: theory and application. Springer, New York.

Ortiz-Miranda D. , Moragues_Faus A. \& Arnalte-Alegre E. (Eds.), (2013). Agriculture in Mediterranean Europe. Between old and new paradigms. Research in Rural Sociology and Development, vol. 19., Emerald, 315 pp.

Paquette, S. \& Domon, G., (2003). Changing ruralities, changing landscapes: Exploring social recomposition using a multi-scale approach. Journal of Rural Studies, 19(4), 425-444. 
Barroso F., Pinto-Correia T.: Land managers' heterogeneity in Mediterranean landscapes - consistencies and contradictions between attitudes and behaviors.

Plieninger, T., Modolell y Mainou, J. \& Konold, W., (2004). Land manager attitudes toward management, regeneration, and conservation of Spanish holm oak savannas (dehesas). Landscape and Urban Planning, 66(3), pp.185-198.

Pinto-Correia T., Barroso F. and Menezes H., (2010). The changing role of farming in a peripheric South European area: the challenge of the landscape amenities demand. In: Wiggering H., Ende H.-P., Knierim A. and Pintar M. and (Eds.): Innovations in European Rural Landscapes (pp. 53-76), Springer, Berlim-Heidelberg.

Pinto-Correia T., Barroso F. and Menezes H., 2013. The Landscape as an Asset in Southern European Fragile Agricultural Systems: Contrasts and Contradictions in Land Managers Attitudes and Practices Landscape Research, DOI: 10.1080/01426397.2013.790948.

Pinto-Correia, T., Gustavsson, R. \& Pirnat J., (2006). Bridging the gap between centrally defined policies and local decisions. Towards more sensitive and creative rural landscape management. Landscape Ecology 21, 333-346.

Pinto-Correia, T., \& Kristensen, L, (2013). Linking research to practice: The landscape as the basis for integrating social and ecological perspectives of the rural. Landscape and Urban Planning, Retrieved April 3, 2013, from http://dx.doi.org/10.1016/j.landurbplan.2013.07.005

Pinto-Correia T. \& Godinho S., (2013). Changing agriculture - changing landscape: what is going on in the high valued Montado landscapes of Southern Portugal? In:Ortiz-Miranda, D., Moragues-Faus, A.M., Arnalte-Alegre, E. (Eds), Agriculture in Mediterranean Europe Between old and new paradigms (pp. 75-90). Research in Rural Sociology and Development, vol. 19, Emerald.

Pinto-Correia T., Gonzalez C., Sutherland L.-A. \& Peneva M., (2014). Lifestyle farming: countryside consumption and transition towards new farming models. In: Sutherland et al (Eds.) Transition Pathways Towards Sustainability in European Agriculture. CABI International.

Pinto-Correia, T. \& Vos W., (2004). Multifunctionality in Mediterranean Landscapes - past and future. In: Jongman R. (Ed.), The New Dimension of the European Landscapes (pp. 135-164), Wageningen FRONTIS Series, Springer.

Primdahl, J. \& Swaffield S.R., (2010) Globalisation and the sustainability of agricultural landscapes, Chapter One in Primdahl \& Swaffield, 1-16.

Renting, H. et al., (2009). Exploring multifunctional agriculture. A review of conceptual approaches and prospects for an integrative transitional framework. Journal of Environmental Management, 90 (SUPPL. 2), pp.112-23.

Richards, G. \& van der Ark, L.A., (2013). Dimensions of cultural consumption among tourists: Multiple correspondence analysis. Tourism Management, 37, 71-76.

Ribeiro, S.C., Ramos I. L., Madeira L., Barroso, F., ,Menezes, H., Pinto-Correia T., (2013). Is land cover an important asset for addressing the subjective landscape dimensions? Land Use Policy 35, 50- 60

Rodrigo, I., \& Veiga, J. F., (2009). Portugal: Natural resources, sustainability and rural development. In K. Bruckmeier \& H. Tovey (Eds.), Rural sustainable development in the knowledge society. England: Ashgate.

Robinson, G., (2008). Sustainable rural systems: sustainable agriculture and rural communities Ashgate, Aldershot. 
Schmitzberger, I., Wrbka, T., Steurer, B., Aschenbrenner, G., Peterseil, J. \& Zechmeister, H.G., (2005). How farming styles influence biodiversity maintenance in Austrian agricultural landscapes. Agriculture, Ecosystems and Environment, 108(3), 274-290.

Selfa, T., Jussaume, R. a. \& Winter, M., (2008). Envisioning agricultural sustainability from field to plate: Comparing producer and consumer attitudes and practices toward "environmentally friendly" food and farming in Washington State, USA. Journal of Rural Studies, 24(3), 262-276.

Swanwick, C., (2009). Society's attitudes to and preferences for land and landscape. Land Use Policy, 26, S62-S75.

Stoate, C., Boatman, N.D., Borralho, R.J., Rio Carvalho, C., de Snoo, G.R., Eden, P., (2001). Ecological impacts of arable intensification in Europe. Journal of Environmental Management 63, 337-365.

Steel, B.S., (1996). Thinking globally and acting locally?: Environmental attitudes, behaviour and activism. Journal of Environmental Management 47 (1), 27-36.

Sutherland, L. A., (2010). Environmental grants and regulations in strategic farm business decision-making: A case study of attitudinal behavior in Scotland. Land Use Policy, 27, 415423.

Van Berkel, D.B., Carvalho-Ribeiro, S., Verburg, P. H. \& Lovett, A., (2011). Identifying assets and constraints for rural development with qualitative scenarios: A case study of Castro Laboreiro, Portugal. Landscape and Urban Planning, 102(2), 127-141.

Van der Ploeg, J.D., Laurent, C., Blondeau, F. \& Bonnafous, P., (2009). Farm diversity, classification schemes and multifunctionality. Journal of Environmental Management, 90(2), S124-31.

Wilson G. A., (2007). Multifunctional Agriculture. A Transition Theory Perspective. CABI, Cromwell Press, Trowbridge.

Valbuena, D., Verburg, P.H. \& Bregt, A.K., (2008). A method to define a typology for agent-based analysis in regional land-use research. Agriculture, Ecosystems and Environment, 128(1-2), 27-36.

Vesala, H.T. \& Vesala, K.M., (2010). Entrepreneurs and producers: Identities of Finnish farmers in 2001 and 2006. Journal of Rural Studies, 26(1), 21-30.

Walford, N., (2003). Productivism is allegedly dead, long live productivism. Evidence of continued productivist attitudes and decision-making in South-East England. Journal of Rural Studies, 19(4), 491-502.

Ward, N., (1993). The agricultural treadmill and the rural environment in the post-productivist era. Sociologia Ruralis 33, 348-364.

Willock, J., Deary, I.J., McGregor, M.M., Sutherland, A., Edwards-Jones, G., Morgan, O., Dent, B., Grieve, R., Gibson, G. \& Austin, E., (1999). Farmers' Attitudes, Objectives, Behaviors, and Personality Traits: The Edinburgh Study of Decision Making on Farms. Journal of Vocational Behavior, 54, 5-36.

Wilson, G. A., (1996). Farmer environmental attitudes and ESA participation. Geoforum, 27(2), 115-131.

Wilson, G.A., (2001). From productivism to post-productivism and back again? Exploring the (un)changed natural and mental landscapes of European agriculture. Transactions of the Institute of British Geographers 26 77-102. 
Barroso F., Pinto-Correia T.: Land managers' heterogeneity in Mediterranean landscapes - consistencies and contradictions between attitudes and behaviors.

Wilson, G.A. \& Rigg, J., (2003). "Post-productivist" agricultural regimes and the South : discordant concepts? Progress in Human Geography 27, 605-631.

Wilson, G.A., (2007). Multifunctional agriculture. In: A Transition Theory Perspective. CABI International, Oxfordshire.

Wilson, G.A., (2008). From 'weak' to 'strong' multifunctionality: Conceptualizing farm-level multifunctional transitional pathways. Journal of Rural Studies, 24, 367-383.

Wilson G.A., (2009). The spatiality of multifunctional agriculture: A human geography perspective. Geoforum, 40, 269-280. 